\title{
Critical Factors Affecting the Innovation Activities of Businesses: Evidence from Binh Dinh Province, Vietnam*
}

\author{
Thi Le Hang NGUYEN ${ }^{1}$, Ngoc Toan PHAM², Vu Phuong Linh DAO \\ Thi Thanh Thuy NGO4, Thi Thanh Binh LE
}

Received: May 18, 2020 Revised: May 24, 2020 Accepted: June 09, 2020

\begin{abstract}
The study investigates the factors influencing the innovation activities in the enterprises in the Binh Dinh Province, Vietnam. By employing the dataset from a survey in 200 typical enterprises in Binh Dinh and using the Exploratory Factor Analysis and regression analysis, we found that there are eight factor groups affecting the innovation activities of enterprises. They include management of innovation promotion; market research capacity; leadership inspiring innovation; culture of innovation; human resources for implementing innovation; network connection; disseminating/sharing knowledge; and impact of producing/serving technology. All these factors strongly affect the innovation activities, which plays an important role in promoting the sustainable development of the Vietnamese enterprises, with the statistical significance level at 1\%. Moreover, findings also show that, among these factors, the market research capacity is the strongest determinant of the innovation activity in the enterprise. An increase of 1 point of capacity of market research will increase the innovation activities in the enterprise by 0.114 point. It is followed by the management of promoting innovation, leadership inspiring innovation, and disseminating and sharing knowledge, with $0.104,0.103$ and 0.102 score, respectively. On the other hand, network connection is the weakest factor, with the score of 0.07 point.
\end{abstract}

Keywords: Innovation, Critical Factor, Enterprise, Vietnam.

JEL Classification Code: O30, O32, M10, O20

\section{Introduction}

\footnotetext{
*Acknowledgements:

The authors gratefully acknowledge financial support from Binh Dinh Province People's Committee for research code: 10-05-2018.

${ }^{1}$ First Author and Corresponding Author. Lecturer, Faculty of Economics and Accounting, Quy Nhon University, Vietnam [Postal Address: 170 An Duong Vuong, Quy Nhon City, Binh Dinh Province, 55000, Vietnam] Email: ntlhang@qnu.edu.vn

${ }^{2}$ Lecturer, School of Accounting, University of Economics Ho Chi Minh City, Vietnam. Email:toanpn@ueh.edu.vn

${ }^{3}$ Lecturer, Faculty of Economics and Accounting, Quy Nhon University, Binh Dinh, Vietnam. Email:daovuphuonglinh@qnu.edu.vn

${ }^{4}$ Lecturer, Faculty of Economics and Accounting, Quy Nhon University, Binh Dinh, Vietnam. Email:ngothithanhthuy@qnu.edu.vn ${ }^{5}$ Lecturer, Faculty of Economics and Accounting, Quy Nhon University, Binh Dinh, Vietnam. Email:lethithanhbinh@qnu.edu.vn

(c) Copyright: The Author(s)

This is an Open Access article distributed under the terms of the Creative Commons Attribution Non-Commercial License (http://Creativecommons.org/licenses/by-nc/4.0/) which permits unrestricted noncommercial use, distribution, and reproduction in any medium, provided the original work is properly cited.
}

This study is an empirical research funded by the People's Committee of Binh Dinh Province which aims to identify the influencing factors of innovation activities in enterprises in Binh Dinh Province, Vietnam. This is the basis for proposing policies and directions for improving the environment for innovation. The authors conducted a convenient sampling and survey of 200 enterprises in Binh Dinh Province. A total of 200 questionaires were delivered and 200 valid questionnaires collected, the corresponding rate of valid votes is $100 \%$.

When conducting innovation at the enterprise level, businesses often have to answer a series of questions such as how to innovate and which aspects should benefit from innovation, such as product innovation, innovation in management organization, innovation in production process, innovation in marketing, and innovation in production technology. According to the Organisation for Economic Cooperation and Development (OECD, 2005), innovation is the implementation of a product, commodity, service, a new or significantly-updated production process, a new 
marketing strategy, new organization structure in operation and external relation.

In Vietnam, according to the Vietnam Chamber of Commerce and Industry (VCCI, 2011), innovation is new thing that is used in commerce. In innovation process, creativity and implementation are often combined together in term of product, production process and organization. At the same time, the innovation of businesses is influenced by many factors including within the enterprise such as business leaders view of innovation (Erdil et al., 2004; Fell et al., 2003) or the creative capacity of employees in the enterprise (Hu et al., 2009; Kheng \& Mahmood, 2013), or external factors such as association, legal framework and industry characteristics (Tran, 2016). Therefore, this study aims to identify innovation activities of enterprises including five aspects of innovation, such as product innovation, manufacturing process innovation, management, organization innovation, marketing innovation, and technological innovation. The factors that affect the innovation activities of enterprises including both internal and external factors.

The structure of this paper consists of six parts; the next section is an overview of the study; the third part presents research methods including research hypotheses, description of research variables and methods of data collection, and data processing; the fourth part presents research results; the fifth part discusses the results; and the final part presents conclusions and policy implications of the research.

\section{Literature Review}

In terms of innovation, studies often focus on five aspects.

First, product innovation is the invention of a new product or significant improvement of an existing product in term of operating features or the intended usage related to the technical standards, components and the materials, the environmental friendliness, etc. (Schumpeter, 1949; Romijn \& Albaladejo, 2002; Hage, 1999; Dibrell et al., 2008).

Second, innovation in production processes includes the fundamental changes in the way of production, machinery or software. Process innovations can be conducted to cut production cost, distribution, quality improvement, creating a new or improved products. Specifically, it is innovating in the implementation of a new design, a new analytical method or a new developments that change the way products are created (Acs \& Audretsch, 1988; Singh \& Singh, 2009; Amara et al, 2009; Jensen \& Webster, 2009).

Third, the marketing innovation is the application of the new marketing methods that create changes in the design, the distribution, the promotion and pricing in order to better identify customer needs and seek the new market or positon for the new product to increase sales, revenue, etc (Singh \& Singh, 2009; Jensen \& Webster, 2009).
Fourth, the innovation in management organization is the application of the new management methods to increase the business efficiency basis of cutting transaction costs and administrative costs, improve the outside relationships to improve knowledge, increase labor productivity, improve work efficiency, etc (Hage, 1999; Jensen \& Webster, 2009; McMillan, 2010).

Fifth, technological innovation includes the small improvements that are small changes in the existing technology platforms that bring small benefits to customers. Or it is technological breakthroughs that apply new technologies that are completely different from existing products (Chandy \& Tellis, 1998; Herrmann et al, 2006; McMillan, 2010).

Depending on the perspective of researchers, there is currently a large body of literature about the influencing factors of innovation activities in enterprises. However, we found that most studies focused on two main research directions: internal factors and external factors.

Regarding internal factors, the research suggests that the innovation process depends on many factors such as: size of the business, the strategy and the business culture, knowledge and experience of the leaders, diverse requirements of customers, human resources of organization, etc. Bhattacharya et al. (2004) argues that firm size and business performance such as revenue and profit growth have a positive impact on the process of innovation in enterprises. Romijn and Albaladejo (2002) posits that the innovation capacity of companies is mainly based on the ability of product innovation. So, it is greatly influenced by the training and experience of managers, the skills of staff, and budgets for research and development activities and training. Prajogo and Sohal (2003) argues that focusing on serving customers is one of the important factors of innovation. The improvement in customer service, which aims to detect and satisfy customer needs through improving the quality of products and services, and creating new product features, is the core of innovation.

Regarding external factors, the research suggests that the innovation activities depend on factors such as operating area, networks connection, government policies, etc. Becheikh et al. (2006) categorized the external influences on the innovation activities, including: areas of activity, geographical area, collaboration and network interaction, the absorption of knowledge and technology, government policy, and cultural environment. Fagerberg and Godinho (2004) suggest that the intensity and quality of interactive relationships in the network have a positive impact on the innovation. With the same perspective, there are studies by Cavusgil et al (2003), Love \& Roper (1999), and Bigliardi \& Dormio (2009). Romijn and Albaladejo (2002) argued that the degree of coherence between firms in the value chain or the geographical distance between firms in the value 
chain, institutional support, etc. has a major influence on the innovation activities of business.

The above studies showed that, depending on the operating characteristics of the units, there are a varieties of determinants of innovation. This is the reason why we conducted the research focusing on the enterprises in Binh Dinh. From the overview of the studies, the innovation in enterprises is basically carried out on the following aspects: product innovation, innovation in production process, innovation in organization/management, marketing innovation and technology innovation. At the same time, the innovation process depends greatly on both internal and external factors to enterprise. This is an important rationale for conducting this study about the factors affecting the innovation activities of enterprises.

\section{Research Methods}

\subsection{Research Process}

To carry out this study, the author has designed the following steps:

\subsection{Hypothesis}

\section{Leaders inspire the innovation (LD)}

Avlonitis et al (1994), Erdil (2004), Fell et al (2003) suggest that administrative factors of the organization contribute to the overall innovation of enterprises. The leaders inspire innovation and play a significant role in the innovation activities of enterprises.

Hypothesis H1: Leaders who inspire innovation have a positive relationship with the innovation activities in enterprises.

\section{Capable human resources contribute to implementing innovation (NL)}

$\mathrm{Hu}$ et al (2009) suggested that the individual creative capacity is the source of creating and implementing the creative ideas in an organization. From this perspective, the foundation of enterprise innovation is ideas from individuals in the enterprise (Neely \& Hii, 1998; Kheng \& Mahmood, 2013).

Hypothesis H2: the capable human resources positively relate to the innovation activities in enterprise.

\section{Management promotings innovation (QL)}

Wan et al (2005) argued that elements of management and promoting innovation such as the degree of empowerment in decision-making, the degree of risk-taking, etc., influence innovation. In addition, Nguyen (2015) also said that good management and suitable policies supporting innovation will have a positive and strong impact on innovation.

Hypothesis H3: Management promoting innovation has a positive relationship with the innovation activities in enterprises.

\section{Market research capacity (TT)}

Chuang et al. (2010) measures the enterprise innovation through enterprise capability, the organizational capability and research and development capability. Findings suggested that the marketing department will identify the demand and issues of the consumer, which are then passed to the research and development (R\&D) team and used as the inputs for research promoting innovation for businesses. This result is consistent with Artz et al. (2003).

Hypothesis H4: Market research capacity is positively associated with innovation activities of enterprises.

\section{Culture of innovation (VH)}

Schulze \& Hoegl (2008), Tran (2016) showed that good practice of innovation culture will contribute to knowledge creation and knowledge personalization plays an important role in creating new product ideas. Therefore, the organization's culture of innovation is reflected in the organizational structure of the management apparatus, human resources, cultural environment, remuneration policies, etc.

Hypothesis H5: Creative innovation culture has a positive relationship with the innovation activities in enterprises.

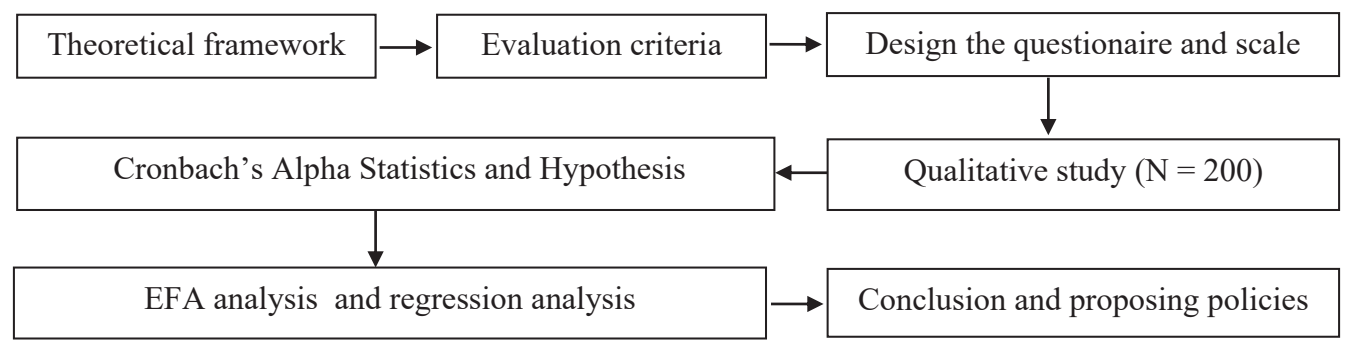

Figure 1: Research process 


\section{Disseminating/ sharing knowledge (CS)}

Darroch (2005) examined the relationship of knowledge management, innovation and business results. It is showed that a enterprise with a good knowledge management will use resources more effectively than other businesses. Therefore, the innovation capacity of the business is also better and the business results are also improved.

Hypothesis H6: Disseminating/sharing knowledge has a positive relationship with the innovation activities in enterprises.

\section{Network Connection $(\mathrm{QH})$}

Prajogo and Sohal (2003) said that focusing on developing customer relationship networks to detect and meet customer needs allows enterprises to continuously improve the quality of products and services with the new features is an important factors of innovation. At the same time, Phung and Le (2013) also said that in order to enhance innovation, countries need to pay attention to the network of businesses through the development of the national innovation system. Nguyen (2015), and Le and Nguyen (2017) also agree with this point of view.

Hypothesis H7: Network connection has a positive relationship with the innovation activities in enterprises.

\section{Impact of manufacturing/ serving technology(CN)}

Herrmann et al (2006), Assink (2006), and O'Connor and Ayers (2005) suggested that the use of differentiated production/service technologies can create a fundamental change in production at a low cost that results in a low price, which can cause a complete change in the existing market.
Hypothesis H8: The impact of production/service technology has a positive relationship with the innovation activities in enterprises.

\subsection{Research Model}

Based on the research hypotheses, we use the multivariate regression model with the dependent variable as innovation in Vietnamese enterprises and eight independent variables mentioned in each hypothesis of the study. The detail regression is as follow:

From the above model, the author proposed the specific regression

$$
\begin{aligned}
\mathrm{DMST}= & \alpha+\beta_{1} * \mathrm{LD}+\beta_{2} * \mathrm{NL}+\beta_{3}^{*} \mathrm{QL}+\beta_{4} * \mathrm{TT}+\beta_{5} \\
& * \mathrm{VH}+\beta_{6} * \mathrm{CS}+\beta_{7} * \mathrm{QH}+\beta_{8} * \mathrm{CN}+\varepsilon
\end{aligned}
$$

Where: $\alpha, \beta_{1}, \beta_{2}, \beta_{3}, \beta_{4}, \beta_{5}, \beta_{6}, \beta_{7}$ and $\beta_{8}$ are coefficients $\varepsilon$ : is error

\subsection{Variables}

In order to serve the process of asking and answering the survey, the author uses the Likert scale ( 5 options), the ratings are as follows: $1=$ "very low", 2 = "low", $3=$ "average", 4 = "high", 5 = "very high". The variables and scales of the research model are determined as follows (see Table 1):

\subsection{Data Collection}

In order to collect data for this study, the authors used a predefined survey questionnaire based on the defined variables and scales. The final questionnaire was built in three stages.

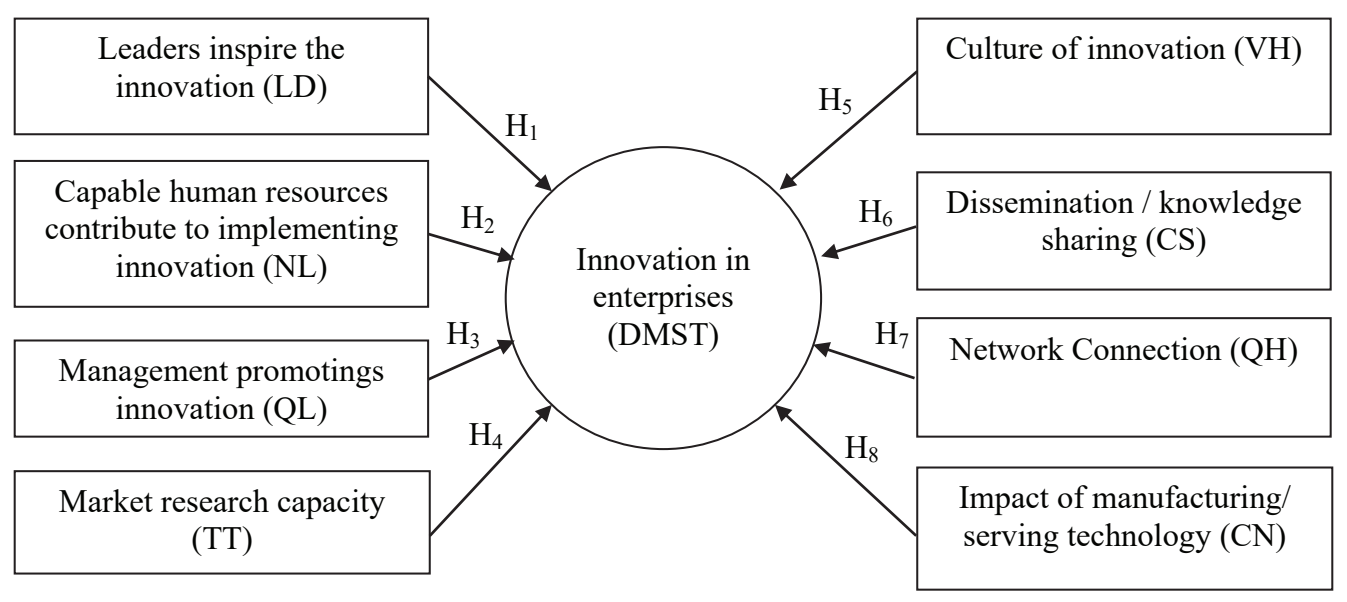

Figure 2: Overview of the research model 
Table 1: Variables and scales

\begin{tabular}{|c|c|c|c|c|}
\hline TT & Factors & Observed variables & Encryption & Source \\
\hline \multicolumn{5}{|c|}{ Dependent variable } \\
\hline \multirow{10}{*}{1} & \multirow{10}{*}{$\begin{array}{l}\text { Product } \\
\text { innovation } \\
\text { (DMSP) }\end{array}$} & The company introduces completely new products to competitors. & DMSP1 & \multirow{10}{*}{$\begin{array}{l}\text { OECD (2005); } \\
\text { Schumpeter } \\
\text { (1949); Romijn } \\
\text { \& Albaladejo } \\
\text { (2002); Hage } \\
\text { (1999); Assink } \\
\text { (2006); Dibrell et } \\
\text { al (2008); Lee \& } \\
\text { Xuan (2019) and } \\
\text { experts interview }\end{array}$} \\
\hline & & $\begin{array}{l}\text { The company offers new products that have not been previously } \\
\text { produced. }\end{array}$ & DMSP2 & \\
\hline & & $\begin{array}{l}\text { The company usually adds new products to the existing product } \\
\text { categories. }\end{array}$ & DMSP3 & \\
\hline & & The company often improves product design. & DMSP4 & \\
\hline & & The company often enhances the quality of manufactured products. & DMSP5 & \\
\hline & & The company often improves the usability of manufactured products. & DMSP6 & \\
\hline & & The company improved its products based on changing input materials. & DMSP7 & \\
\hline & & $\begin{array}{l}\text { The company innovates products based on the application of new } \\
\text { knowledge and technology. }\end{array}$ & DMSP8 & \\
\hline & & $\begin{array}{l}\text { The company usually creates products that are suitable for consumers' } \\
\text { tastes. }\end{array}$ & DMSP9 & \\
\hline & & The company often updates the quality standards for its products. & DMSP10 & \\
\hline \multirow{7}{*}{2} & \multirow{7}{*}{$\begin{array}{l}\text { Innovation in } \\
\text { production } \\
\text { processes } \\
\text { (DMQT) }\end{array}$} & $\begin{array}{l}\text { The company often improves its manufacturing methods to } \\
\text { manufacture products. }\end{array}$ & DMQT1 & \multirow{7}{*}{$\begin{array}{l}\text { OECD (2005); } \\
\text { Acs \& Audretch } \\
\text { (1988); Singh \& } \\
\text { Singh (2009); } \\
\text { Amara et al } \\
\text { (2009); Jensen \& } \\
\text { Webster (2009) } \\
\text { and experts } \\
\text { interview }\end{array}$} \\
\hline & & $\begin{array}{l}\text { The company often makes significant improvements or new methods in } \\
\text { supplying, transporting, providing input for manufacturing products. }\end{array}$ & DMQT2 & \\
\hline & & The company often improves the delivery method. & DMQT3 & \\
\hline & & $\begin{array}{l}\text { The company often updates production management methods to the } \\
\text { production process. }\end{array}$ & DMQT4 & \\
\hline & & $\begin{array}{l}\text { The company has applied software technology in its manufacturing } \\
\text { process. }\end{array}$ & DMQT5 & \\
\hline & & The company periodically renews production equipment. & DMQT6 & \\
\hline & & The company often modernize the production process. & DMQT7 & \\
\hline \multirow{9}{*}{3} & \multirow{9}{*}{$\begin{array}{l}\text { Management } \\
\text { innovation } \\
\text { (DMQL) }\end{array}$} & $\begin{array}{l}\text { The company is always improving and adjusting its organizational } \\
\text { structure to improve management effectiveness. }\end{array}$ & DMQL1 & \multirow{9}{*}{$\begin{array}{l}\text { OECD (2005); } \\
\text { Singh \& Singh } \\
\text { (2009); Jensen \& } \\
\text { Webster (2009) } \\
\text { and experts } \\
\text { interview }\end{array}$} \\
\hline & & $\begin{array}{l}\text { The company always applies new management methods (for example, } \\
\text { supply chain management, operational model design, knowledge } \\
\text { management, etc.). }\end{array}$ & DMQL2 & \\
\hline & & $\begin{array}{l}\text { The company always implements new methods in personnel } \\
\text { organization, human resource management and decision making. }\end{array}$ & DMQL3 & \\
\hline & & $\begin{array}{l}\text { The company always applies new methods to promote external } \\
\text { relations with other organizations or companies. }\end{array}$ & DMQL4 & \\
\hline & & $\begin{array}{l}\text { The company often applies quality management systems, innovations } \\
\text { in the operation process. }\end{array}$ & DMQL5 & \\
\hline & & The company often shares knowledge internally. & DMQL6 & \\
\hline & & $\begin{array}{l}\text { The company applies a decentralized management decision-making } \\
\text { approach. }\end{array}$ & DMQL7 & \\
\hline & & $\begin{array}{l}\text { The company is interested in developing the affiliate network in the } \\
\text { value chain of the active industry. }\end{array}$ & DMQL8 & \\
\hline & & $\begin{array}{l}\text { The company always focuses on improving the qualifications and skills } \\
\text { of managers. }\end{array}$ & DMQL9 & \\
\hline
\end{tabular}




\begin{tabular}{|c|c|c|c|c|}
\hline \multirow{7}{*}{4} & \multirow{7}{*}{$\begin{array}{c}\text { Marketing } \\
\text { innovation } \\
\text { (DMMAR) }\end{array}$} & $\begin{array}{l}\text { The company always applies new techniques to promote the sale of } \\
\text { products, goods and services. }\end{array}$ & DMMAR1 & \multirow{7}{*}{$\begin{array}{l}\text { OECD (2005); } \\
\text { Hage (1999); } \\
\text { Jensen \& } \\
\text { Webster (2009); } \\
\text { McMillan (2010) } \\
\text { and experts } \\
\text { interview }\end{array}$} \\
\hline & & $\begin{array}{l}\text { The company always utilizes new media to promote products, goods } \\
\text { and services. }\end{array}$ & DMMAR2 & \\
\hline & & $\begin{array}{l}\text { The company always has a new way of selling or distributing products, } \\
\text { goods and services. }\end{array}$ & DMMAR3 & \\
\hline & & $\begin{array}{l}\text { The company always applies new methods of pricing products, goods } \\
\text { and services. }\end{array}$ & DMMAR4 & \\
\hline & & $\begin{array}{l}\text { The company is always updated with new tastes and market } \\
\text { trends. }\end{array}$ & DMMAR5 & \\
\hline & & $\begin{array}{l}\text { The company always changes effective sales methods based on } \\
\text { customer suggestions. }\end{array}$ & DMMAR6 & \\
\hline & & $\begin{array}{l}\text { The company always pays attention to the price of its products, goods } \\
\text { and services with competitors. }\end{array}$ & DMMAR7 & \\
\hline \multirow{8}{*}{5} & \multirow{8}{*}{$\begin{array}{l}\text { Technology } \\
\text { innovation } \\
\text { (DMCN) }\end{array}$} & $\begin{array}{l}\text { The company is interested in investing in technology research and } \\
\text { development. }\end{array}$ & DMCN1 & \multirow{8}{*}{$\begin{array}{c}\text { Afuah } \\
\text { (2003);Chandy } \\
\text { \&Tellis (1998); } \\
\text { Herrmann et al } \\
\text { (2006); McMillan } \\
\text { (2010); Lee \& } \\
\text { Xuan (2019) and } \\
\text { experts interview }\end{array}$} \\
\hline & & $\begin{array}{l}\text { The company often upgrades its production technology and service } \\
\text { methods. }\end{array}$ & DMCN2 & \\
\hline & & $\begin{array}{l}\text { The company is interested in setting up science and technology } \\
\text { development fund. }\end{array}$ & DMCN3 & \\
\hline & & $\begin{array}{l}\text { The company is interested in investing in new and modern } \\
\text { technologies. }\end{array}$ & DMCN4 & \\
\hline & & $\begin{array}{l}\text { The company applies modern technology in accordance with the staff } \\
\text { performance. }\end{array}$ & DMCN5 & \\
\hline & & The company exploits well the equipment productivity. & DMCN6 & \\
\hline & & $\begin{array}{l}\text { The company focuses on the application of technology to the } \\
\text { manufacturing process. }\end{array}$ & DMCN7 & \\
\hline & & $\begin{array}{l}\text { The company always focuses on using environmentally-friendly } \\
\text { technology. }\end{array}$ & DMCN8 & \\
\hline \multicolumn{5}{|c|}{ Independent variables } \\
\hline \multirow{5}{*}{1} & \multirow{5}{*}{$\begin{array}{l}\text { Leaders } \\
\text { inspire } \\
\text { innovation } \\
\text { (LD) }\end{array}$} & $\begin{array}{l}\text { Company leaders give a clear vision of the future development of the } \\
\text { business. }\end{array}$ & LD1 & \multirow{5}{*}{$\begin{array}{l}\text { Avlonitis et al } \\
\text { (1994); Erdil } \\
\text { (2004); Fell et } \\
\text { al (2003) and } \\
\text { experts interview }\end{array}$} \\
\hline & & $\begin{array}{l}\text { Company leaders attract people to care and implement plans for the } \\
\text { future of the business. }\end{array}$ & LD2 & \\
\hline & & $\begin{array}{l}\text { Company leaders often listen and encourage new ideas of } \\
\text { employees. }\end{array}$ & LD3 & \\
\hline & & $\begin{array}{l}\text { Company leaders always care and support individuals with innovative } \\
\text { ideas. }\end{array}$ & LD4 & \\
\hline & & $\begin{array}{l}\text { Company leaders always show enthusiasm for innovation and } \\
\text { completed work. }\end{array}$ & LD5 & \\
\hline \multirow{4}{*}{2} & \multirow{4}{*}{$\begin{array}{l}\text { Human } \\
\text { resources } \\
\text { are capable } \\
\text { of realizing } \\
\text { innovation } \\
\text { (NL) }\end{array}$} & $\begin{array}{l}\text { Workers have the ability to critically analyze current practices to find } \\
\text { better ways. }\end{array}$ & NL1 & \multirow{4}{*}{$\begin{array}{l}\text { Hu et al (2009); } \\
\text { Neely \& Hii, } \\
\text { (1998); Kheng \& } \\
\text { Mahmood (2013) } \\
\text { and experts } \\
\text { interview }\end{array}$} \\
\hline & & $\begin{array}{l}\text { Employees in the company often contribute valuable information and } \\
\text { initiatives. }\end{array}$ & NL2 & \\
\hline & & $\begin{array}{l}\text { Employees have the capacity to identify and acquire relevant new } \\
\text { knowledge from the outside. }\end{array}$ & NL3 & \\
\hline & & Workers have the ability to exploit new knowledge for innovation. & NL4 & \\
\hline
\end{tabular}




\begin{tabular}{|c|c|c|c|c|}
\hline \multirow{7}{*}{3} & \multirow{7}{*}{$\begin{array}{l}\text { Management } \\
\text { promotes } \\
\text { innovation } \\
(\mathrm{QL})\end{array}$} & $\begin{array}{l}\text { The company has a clear, relevant and effective way to bring new ideas } \\
\text { and new solutions. }\end{array}$ & QL1 & \multirow{7}{*}{$\begin{array}{l}\text { Wan et al (2005); } \\
\text { Nguyen (2015); } \\
\text { Hoang \& Ngoc } \\
\text { (2019) and } \\
\text { experts interview }\end{array}$} \\
\hline & & $\begin{array}{l}\text { The company has an appropriate process and criteria for choosing } \\
\text { product innovation ideas. }\end{array}$ & QL2 & \\
\hline & & The company always provides feedback to employees about their ideas. & QL3 & \\
\hline & & $\begin{array}{l}\text { Everyone has the opportunity to be empowered to perform the } \\
\text { assigned work in the most creative and effective manner. }\end{array}$ & QL4 & \\
\hline & & $\begin{array}{l}\text { The coordination between the various departments and divisions in the } \\
\text { company is very effective to turn new ideas into practical results. }\end{array}$ & QL5 & \\
\hline & & $\begin{array}{l}\text { The company pays attention to the policies of rewarding and } \\
\text { encouraging employees to innovate. }\end{array}$ & QL6 & \\
\hline & & $\begin{array}{l}\text { The company has implemented many training programs to improve the } \\
\text { innovation capacity for employees. }\end{array}$ & QL7 & \\
\hline \multirow{7}{*}{4} & \multirow{7}{*}{$\begin{array}{l}\text { Market } \\
\text { research } \\
\text { capacity } \\
(\mathrm{TT})\end{array}$} & $\begin{array}{l}\text { The company performs well market research to understand the needs } \\
\text { of its customers. }\end{array}$ & TT1 & \multirow{7}{*}{$\begin{array}{l}\text { Chuang et al } \\
\text { (2010); Artz et al } \\
\text { (2003); Basuki } \\
\text { et al. (2020) and } \\
\text { experts interview }\end{array}$} \\
\hline & & The company does well in market research to shape a clear new product. & TT2 & \\
\hline & & $\begin{array}{l}\text { The company does well in market research to identify market } \\
\text { opportunities. }\end{array}$ & TT3 & \\
\hline & & The company usually collects information about customers. & TT4 & \\
\hline & & The company usually collects information about competitors. & TT5 & \\
\hline & & $\begin{array}{l}\text { The company usually collects market information from the relational } \\
\text { network (from customers, suppliers, partners, ...). }\end{array}$ & TT6 & \\
\hline & & $\begin{array}{l}\text { The company establishes good relationships with customers to obtain } \\
\text { timely feedback. }\end{array}$ & TT7 & \\
\hline \multirow{4}{*}{5} & \multirow{4}{*}{$\begin{array}{l}\text { Innovative } \\
\text { culture } \\
\text { (VH) }\end{array}$} & $\begin{array}{l}\text { The company cares about creating an environment to encourage } \\
\text { individuals to do things in a different way. }\end{array}$ & $\mathrm{VH}$ & \multirow{4}{*}{$\begin{array}{c}\text { Schulze và } \\
\text { Hoegl (2008); } \\
\text { Tran (2016) and } \\
\text { experts interview }\end{array}$} \\
\hline & & The company encourages people to try new ways of working. & $\mathrm{VH} 2$ & \\
\hline & & $\begin{array}{l}\text { When experimenting with a new way of working, mistakes are } \\
\text { sympathetic / shared within the company. }\end{array}$ & VH3 & \\
\hline & & $\begin{array}{l}\text { In the company, employees are very proactive in making suggestions/ } \\
\text { suggestions for finishing work. }\end{array}$ & $\mathrm{VH} 4$ & \\
\hline \multirow{4}{*}{6} & \multirow{4}{*}{$\begin{array}{l}\text { Disseminate } \\
\text { knowledge } \\
\text { sharing } \\
\text { (CS) }\end{array}$} & $\begin{array}{l}\text { The company has forms of documents and regulations that workers can } \\
\text { easily access when they need it. }\end{array}$ & CS1 & \multirow{4}{*}{$\begin{array}{l}\text { Darroch (2005); } \\
\text { Chiu \& Lin } \\
\text { (2019) and } \\
\text { experts interview }\end{array}$} \\
\hline & & $\begin{array}{l}\text { The company periodically sends relevant reports and information to } \\
\text { employees. }\end{array}$ & CS2 & \\
\hline & & $\begin{array}{l}\text { The company has databases, meeting rooms to display and } \\
\text { disseminate knowledge. }\end{array}$ & $\operatorname{cs} 3$ & \\
\hline & & $\begin{array}{l}\text { The company often holds seminars and workshops to share and } \\
\text { disseminate new knowledge to all members. }\end{array}$ & CS4 & \\
\hline \multirow{4}{*}{7} & \multirow{4}{*}{$\begin{array}{l}\text { Relationship } \\
\text { network } \\
\text { (QH) }\end{array}$} & The company established good relationships with partners. & QH1 & \multirow{4}{*}{\begin{tabular}{|l} 
Prajogo và Sohal \\
(2003); Phung \\
\& Le (2013); \\
Nguyen (2015); \\
Le \& Nguyen \\
(2017) and \\
experts interview
\end{tabular}} \\
\hline & & $\begin{array}{l}\text { The company develops strong partnerships with universities or } \\
\text { research organizations, design consultants, technology transfer. }\end{array}$ & QH2 & \\
\hline & & The company has the ability to create new partnerships. & QH3 & \\
\hline & & The company is able to exploit business networks. & QH4 & \\
\hline \multirow{3}{*}{8} & \multirow{3}{*}{$\begin{array}{l}\text { Impact of } \\
\text { production } \\
\text { technology / } \\
\text { service } \\
\text { (CN) }\end{array}$} & $\begin{array}{l}\text { Technology has a significant influence on the innovation process in the } \\
\text { company. }\end{array}$ & CS1 & \multirow{3}{*}{\begin{tabular}{|c} 
Herrmann et al \\
(2006); Assink \\
(2006); O'Connor \\
\& Ayers (2005); \\
Lee \& Xuan \\
(2019) and \\
experts interview
\end{tabular}} \\
\hline & & $\begin{array}{l}\text { The company often invests and researches to innovate production/ } \\
\text { service technology. }\end{array}$ & CS2 & \\
\hline & & $\begin{array}{l}\text { The degree of innovation and success of the company depends on the } \\
\text { advance of applied technology. }\end{array}$ & CS3 & \\
\hline
\end{tabular}




\section{Phase 1: Developing a draft survey.}

We conducted an overview of domestic and foreign studies on innovation in enterprises to identify gaps to be studied. Next, based on the theory of innovation and preliminarily practical data collection from the enterprises in Binh Dinh, we came up with a draft questionnaire with two main information: (i) general information about the business, (ii) survey information.

\section{Phase 2: Consulting with experts and conducting the pre-test survey to complete plans and targets needed to be surveyed.}

For this stage, the authors conducted direct interviews with experts who are university lecturers, researchers in institutes, members of the Board of Directors, and heads or deputy heads of enterprises. A total of 20 people and 20 enterprises pre-tested the survey. At this stage, the research team conducted a direct interview on the questionnaire designed in Phase 1 and exchanged ideas about research with experts and businesses to assess whether the questionnaire is appropriate or necessates additions or adjustments

\section{Phase 3: Designing the official questionnaire.}

Based on the results of the interviews in Phase 2, we designed a complete questionaire with a view to increase the effectiveness, accuracy and feasibility of questions. The authors have organized the first workshop to publish the results of expert interviews, pre-test survey results and official questionnaire. We have received valuable comments and feedbacks from the experts, consumers, businesses that allows us to finalized the questionnaire.

At the same time, the survey was sent directly to the selected 200 enterprises together witha recommendation letter of the host agency introducing this project. To ensure a representative sample, businesses surveyed had to satisfied the following criteria: (1) enterprises operate in three different sectors: (i) industry and construction; (ii) trade and service; (iii) agriculture, forestry and fishery under the Government Decree No. 32/2018/ND-CP; (2) they have the legal structure of a joint-stock company, limitedliability company, and private company; (3) they are located in differnt areas from the delta, mountainous and city; (4) the sample includes enterprises inside the industrial parks, industrial zones and outside these regions.

\subsection{Methods of Data Analysis}

From the valid questionnaires collected, the authors turned to Excel and coded each part of the survey questionnaire. Next, all data were processed through the SPSS 22.0 software. The author conducted a number of analyses and testing as follows:
Descriptive Statistics and hypothesis of mean testing: Descriptive statistics allows to calculate the average for the factors affecting innovation while the average value test is used to compare the average value of the factors with the average value of 3 that allows to evaluate the level of influence of the factors.

Cronbach's Alpha Analysis: The purpose of Cronbach's Alpha analysis is to test the reliability of scales and survey data to assess the correlation among the observed variables. Most of researchers accept that Cronbach's Alpha levels of 0.8 or higher is good; from 0.7 to 0.8 it is usable. If the concepts in question are new, this coefficient is only required to reachabove 0.6. With Cronbach's Alpha level greater than or equal to 0.8, the scale is considered a good measurement, the questions are designed closely, and the scales are actually correlated with each other to achieve high reliability (Hoang \& Chu, 2011).

EFA exploratory factor analysis: When analyzing discovery factors, researchers often care about some standards. First, KMO coefficient (Kaiser-Meyer-Olkin) $\geq 0.5$, the significance level of Bartlett $\leq 0.05$ test. KMO is a criterion used to consider the appropriateness of EFA, $0.5 \leq \mathrm{KMO} \leq 1$, then factor analysis is appropriate. Bartlett's Test examined the hypothesis of the correlation between observed variables in the overall. If this test is statistically significant ( $\mathrm{Sig} \leq 0.05)$, the observed variables are correlated in the overall. Second, factor loading coefficient $>0.45$. If any observed variable has factor loading coefficient $\leq 0.45$, it will be disqualified. Third, the scale is accepted when the total variance extracted $\geq 50 \%$ and eigenvalue is greater than 1 . The fourth criterion is the difference in factor loading coefficient of an observed variable among factors $\geq 0.3$ to ensure the distinguishing value among factors is protected (Hoang \& Chu, 2011). According to Dinh et al. (2018), Factor loading is the norm to ensure the practical meaning of EFA, Factor loading $>0.3$ is considered to be the minimum, Factor loading $>0.4$ is considered Important, $\geq 0.5$ is considered to have practical significance.

\section{Research Results}

\subsection{Cronbach's Alpha}

In this study, the observed variables of the independent and dependent variables were selected when the Cronbach's Alpha coefficient was 0.6 or higher and the total correlation coefficient was greater than 0.3 . The results in Table 2 show that the variables in the research model are reliable. The test results also show that Cronbach's Alpha of the dependent and independent variables are larger than 0.7. Thus, both the dependent and independent variables satisfy the reliability, thus, no variables are excluded. Because the results of testing the scales show that all scales are suitable and reliable, they are statistically significant to use the EFA discovery factor analysis for innovation activities of businesses in Binh Dinh Province. 
Table 2: The Cronbach's Alpha coefficients

\begin{tabular}{|l|l|l|}
\hline Reliability Statistics & N of Items & Cronbach's Alpha \\
\hline 1. For dependent variables & 10 & 0.953 \\
\hline Product innovation & 07 & 0.937 \\
\hline Innovating the manufacturing process & 09 & 0.956 \\
\hline Innovation in management organization & 07 & 0.902 \\
\hline Innovation in marketing & 08 & 0.949 \\
\hline Technological innovation & & 0.912 \\
\hline 2. For independent variables & 05 & 0.853 \\
\hline Leaders inspire innovation & 04 & 0.915 \\
\hline Human resources are capable of implementing innovation & 07 & 0.911 \\
\hline Management promoting innovation & 07 & 0.860 \\
\hline Market research capacity & 04 & 0.740 \\
\hline Creative innovation culture & 04 & 0.852 \\
\hline Knowledge disseminating/ sharing & 04 & 0.841 \\
\hline Network connection & 03 & \\
\hline Impact of producing/ serving technology & & \\
\hline
\end{tabular}

Table 3: Results of the total variance of the data are explained

\begin{tabular}{|c|c|c|c|c|c|c|c|c|c|}
\hline \multirow{2}{*}{ Component } & \multicolumn{3}{|c|}{ Initial Eigenvalues } & \multicolumn{2}{c|}{$\begin{array}{c}\text { Extraction Sums of Squared } \\
\text { Loadings }\end{array}$} & \multicolumn{3}{c|}{$\begin{array}{c}\text { Rotation Sums of Squared } \\
\text { Loadings }\end{array}$} \\
\cline { 2 - 10 } & Total & $\begin{array}{c}\% \text { of } \\
\text { Variance }\end{array}$ & $\begin{array}{c}\text { Cumulative } \\
\%\end{array}$ & Total & $\begin{array}{c}\% \text { of } \\
\text { Variance }\end{array}$ & $\begin{array}{c}\text { Cumulative } \\
\%\end{array}$ & Total & $\begin{array}{c}\% \text { of } \\
\text { Variance }\end{array}$ & $\begin{array}{c}\text { Cumulative } \\
\%\end{array}$ \\
\hline 1 & 6.271 & 16.502 & 16.502 & 6.271 & 16.502 & 16.502 & 4.806 & 12.647 & 12.647 \\
\hline 2 & 4.961 & 13.057 & 29.558 & 4.961 & 13.057 & 29.558 & 4.680 & 12.316 & 24.963 \\
\hline 3 & $4 . .323$ & 11.376 & 40.934 & 4.323 & 11.376 & 40.934 & 3.864 & 10.169 & 35.131 \\
\hline 4 & 2.857 & 7.518 & 48.452 & 2.857 & 7.518 & 48.452 & 2.883 & 7.586 & 42.717 \\
\hline 5 & 2.601 & 6.845 & 55.298 & 2.601 & 6.845 & 55.298 & 2.863 & 7.535 & 50.253 \\
\hline 6 & 2.456 & 6.463 & 61.761 & 2.456 & 6.463 & 61.761 & 2.836 & 7.462 & 57.715 \\
\hline 7 & 1.822 & 4.796 & 66.557 & 1.822 & $4, .796$ & 66.557 & 2.605 & 6.854 & 64.569 \\
\hline 8 & 1.660 & 4.370 & 70.926 & 1.660 & 4.370 & 70.926 & 2.416 & 6.357 & 70.926 \\
\hline 9 & .975 & 2.565 & 73.492 & & & & & \\
\hline
\end{tabular}

\subsection{Exploratory Factor Analysis (EFA)}

On the basis of testing the reliability and correlation with Cronbach's Alpha, we conducted an EFA discovery factor analysis, the results were as follows:

\section{For independent variables:}

According to KMO and Bartlett's Test, we have a KMO coefficient $=0.677>0.5$ (greater than the minimum to ensure the appropriate EFA analysis) and Sig level of Bartlett's test is $0.000<0.05$ means that the variables correlated in overall. Thus, the EFA analysis for the independent variables is really meaningful. At the same time, the analysis results in Table 3 show that, based on criterion of Eigenvalue $>1$, there are eight groups of factors drawn. The total variance extracted is $70.926 \%$ (greater than the standard level $>50 \%$ ), which means $70.926 \%$ of the data variation is explained by eight factor groups. 
In addition, for Factor Loading in groups, according to Hair et al. (2010), in order to ensure the practical significance level of EFA, Factor Loading $>0.3$ is considered to be a minimum, Factor Loading $>0.4$ is considered important, Factor Loading $\geq 0.5$ is considered to be of practical significance. As a result, when using the Varimax rotation to obtain the best load coefficient, we obtained eight groups of influence factors, including: (1) Management of innovation promotion (with seven variables); (2) Market research capacity (with seven variables); (3) Leaders inspire innovation (with five variables); (4) Innovative culture (with four variables); (5) Capable human resources for implementing innovation (with four variables); (6) Network connection (with four variables); (7) Dissemination of knowledge sharing (with four variables) and (8) Impact of producing /servingtechnology (with three variables) (see Table 4).

Table 4: Factor rotation matrix

\begin{tabular}{|c|c|c|c|c|c|c|c|c|}
\hline & & & & $\mathrm{Co}_{0}$ & & & & \\
\hline & 1 & 2 & 3 & 4 & 5 & 6 & 7 & 8 \\
\hline QL1 & .862 & & & & & & & \\
\hline QL5 & .858 & & & & & & & \\
\hline QL4 & .839 & & & & & & & \\
\hline QL6 & .787 & & & & & & & \\
\hline QL3 & .772 & & & & & & & \\
\hline QL2 & .759 & & & & & & & \\
\hline QL7 & .723 & & & & & & & \\
\hline TT7 & & .876 & & & & & & \\
\hline TT5 & & .866 & & & & & & \\
\hline TT2 & & .856 & & & & & & \\
\hline TT3 & & .822 & & & & & & \\
\hline TT1 & & .786 & & & & & & \\
\hline TT4 & & .758 & & & & & & \\
\hline TT6 & & .703 & & & & & & \\
\hline LD3 & & & .971 & & & & & \\
\hline LD1 & & & .928 & & & & & \\
\hline LD2 & & & .871 & & & & & \\
\hline LD5 & & & .757 & & & & & \\
\hline LD4 & & & .722 & & & & & \\
\hline VH3 & & & & .900 & & & & \\
\hline $\mathrm{VH} 2$ & & & & .879 & & & & \\
\hline VH1 & & & & .835 & & & & \\
\hline VH4 & & & & .646 & & & & \\
\hline NL2 & & & & & .879 & & & \\
\hline NL1 & & & & & .872 & & & \\
\hline NL3 & & & & & .775 & & & \\
\hline NL4 & & & & & .764 & & & \\
\hline QH1 & & & & & & .880 & & \\
\hline QH4 & & & & & & .824 & & \\
\hline QH3 & & & & & & .755 & & \\
\hline $\mathrm{QH} 2$ & & & & & & .632 & .568 & \\
\hline CS4 & & & & & & & .788 & \\
\hline CS2 & & & & & & & .740 & \\
\hline CS1 & & & & & & & .733 & \\
\hline CS3 & & & & & & & .690 & \\
\hline CN2 & & & & & & & & .877 \\
\hline CN1 & & & & & & & & .851 \\
\hline CN3 & & & & & & & & .796 \\
\hline
\end{tabular}




\section{For dependent variables:}

According to KMO and Bartlett's Test tables, we have a $\mathrm{KMO}$ coefficient $=0.743>0.5$ (greater than the minimum to ensure appropriate EFA analysis) and Sig level of Bartlett's test is $0.000<0.05$ means that the variables correlated in overall. Therefore, the EFA analysis for the dependent variables is meaningful. From the above variance table, according to criterion of Eigenvalue $>1$, there are five factors drawn. The total variance extracted is $73.387 \%$ (greater than the standard level $>50 \%$ ), that is $73.387 \%$ of the data variation is explained by these factors.

Moreover, the results from using Varimax rotation to obtain the best load coefficient, we obtained five groups of factors of innovation, including: (1) Product innovation (with 10 variables); (2) Innovation of management organization (there are nine variables); (3) Technological innovation (with eight variables); (4) Innovation in manufacturing process (there are seven variables); and (5) Innovation in marketing (with seven variables). Therefore, the results of the factor analysis show that the research has drawn eight groups of factors affecting the innovation factors in enterprises. All of which are reliable and statistically significant (see Table 5).

\subsection{Regression Analysis}

In order to perform regression analysis, we calculated the mean to represent the dependent and independent variables. The results of regression analysis assessing the impact of factors on innovation are as follows (see Table 6):

The regression results table shows that all independent variables are really affecting innovation dependent variables (this is concluded through t-test with Sig level of the test are all less than $1 \%, 5 \%$ or $10 \%$ ). The result also shows that

Table 5: Results of the total variance of the data are explained

\begin{tabular}{|c|c|c|c|c|c|c|c|c|c|}
\hline \multirow{2}{*}{ Component } & \multicolumn{4}{|c|}{ Initial Eigenvalues } & \multicolumn{2}{c|}{$\begin{array}{c}\text { Extraction Sums of Squared } \\
\text { Loadings }\end{array}$} & \multicolumn{3}{c|}{$\begin{array}{c}\text { Rotation Sums of Squared } \\
\text { Loadings }\end{array}$} \\
\cline { 2 - 10 } & Total & $\begin{array}{c}\% \text { of } \\
\text { Variance }\end{array}$ & $\begin{array}{c}\text { Cumulative } \\
\%\end{array}$ & Total & $\begin{array}{c}\% \text { of } \\
\text { Variance }\end{array}$ & $\begin{array}{c}\text { Cumulative } \\
\%\end{array}$ & $\begin{array}{c}\text { Total } \\
\% \text { of } \\
\text { Variance }\end{array}$ & $\begin{array}{c}\text { Cumulative } \\
\%\end{array}$ \\
\hline 1 & 9.415 & 22.964 & 22.964 & 9.415 & 22.964 & 22.964 & 7.279 & 17.754 & 17.754 \\
\hline 2 & 7.126 & 17.380 & 40.344 & 7.126 & 17.380 & 40.344 & 6.839 & 16.681 & 34.436 \\
\hline 3 & 5.644 & 13.767 & 54.111 & 5.644 & 13.767 & 54.111 & 6.029 & 14.705 & 49.141 \\
\hline 4 & 4.612 & 11.248 & 65.359 & 4.612 & 11.248 & 65.359 & 5.306 & 12.942 & 62.082 \\
\hline 5 & 3.292 & 8.028 & 73.387 & 3.292 & 8.028 & 73.387 & 4.635 & 11.305 & 73.387 \\
\hline 6 & .963 & 2.350 & 75.737 & & & & & & \\
\hline
\end{tabular}

Table 6: Results of regression analysis

\begin{tabular}{|c|c|c|c|c|c|c|c|c|}
\hline & \multirow{2}{*}{ Model } & \multicolumn{2}{|c|}{$\begin{array}{l}\text { Unstandardized } \\
\text { Coefficients }\end{array}$} & \multirow{2}{*}{$\begin{array}{c}\begin{array}{c}\text { Standardized } \\
\text { Coefficients }\end{array} \\
\text { Beta } \\
\end{array}$} & \multirow[t]{2}{*}{$\mathbf{t}$} & \multirow{2}{*}{ Sig } & \multicolumn{2}{|c|}{ Collinearity Statistics } \\
\hline & & B & Std. Error & & & & Tolerance & VIF \\
\hline \multirow{9}{*}{1} & (Constant) & .708 & .148 & & 4.781 & .000 & & \\
\hline & LD & .103 & .013 & .365 & 7.849 & .000 & .860 & 1.162 \\
\hline & $\mathrm{NL}$ & .073 & .013 & .255 & 5.608 & .000 & .897 & 1.115 \\
\hline & QL & .104 & .016 & .308 & 6.370 & .000 & .795 & 1.258 \\
\hline & TT & .114 & .023 & .221 & 5.061 & .000 & .973 & 1.028 \\
\hline & $\mathrm{VH}$ & .092 & .015 & .274 & 5.985 & .000 & .887 & 1.128 \\
\hline & CS & .102 & .026 & .176 & 3.920 & .000 & .920 & 1.087 \\
\hline & $\mathrm{QH}$ & .070 & .017 & .200 & 4.015 & .000 & .752 & 1.330 \\
\hline & $\mathrm{CN}$ & .076 & .011 & .325 & 7.085 & .000 & .884 & 1.131 \\
\hline
\end{tabular}


due to the magnification coefficents of VIF are less than 10, the level indicates the serious multi-collinearity, there is no symptom of multicollinearity in this model.

Moreover, the value of $\mathrm{R}^{2}$ of the model is $64.5 \%$, showing that the independent variables explain the high fluctuation of dependent variables. In addition, the results of testing the suitability of the regression function through $\mathrm{F}$ statistics from ANOVA table also show that the model is really suitable (Sig level of the test is very small 0.000). Therefore, based on the regression results table, we have a regression equation for the factors that influence innovation activities of enterprises as follows:

\section{DMST $=0.708+0.103 * \mathrm{LD}+0.073 * \mathrm{NL}+\mathbf{0 . 1 0 4} * \mathrm{QL}$ $+0.114 * \mathrm{TT}+0.092 * \mathrm{VH}+0.102 * \mathrm{CS}+0.070 * \mathrm{QH}+$ $0.076 * \mathrm{CN}$}

On the other hand, through the standardized beta coefficient column, we can see that the labor factor has the strongest impact on the innovation, with the standardized beta of 0.365 , followed by industry and management, with the standardized beta is 0.325 and 0.308 , respectively. The lowest effect on the dependent variable is CS factor with standardized beta of only 0.176 . Other factors such as NL, TT, VH and QH have similar levels of influence.

\section{Discussion and Policy Implications}

The regression results show that there are eight factors influencing the innovation activities and all have positive effects with the strongly statistical significance. However, there are only four factors that have a strong impact on innovation with a beta greater than 1 . Therefore, with the limited resources, to promote innovation, the businesses need to focus on resources allocation with the order of priority of market research capacity, management promoting innovation, leadership inspiring innovation and disseminating/ sharing knowledge.

\section{Firstly, improving market research capacity}

In order to improve market research capacity, businesses need to focus on improving the criterion of their weakness to create efficiency. The enterprises can set the priority: (i) improving relationships with their customers, suppliers, and partners to quickly and timely facilitate the market information; (ii) focus on capturing the needs of customers, especially the target customers. Capturing customers' tastes will help businesses have a reasonable product innovation strategies to best meet those needs; (iii) it is necessary to be sensitive in identifying market opportunities and creating a customer data system to develop a customer care system, increase accessibility, and promote product information to customers. In particular, it is necessary to develop an information system on the competitors in order to implement plans and strategies when the competitors change their tactics to dominate the market.

\section{Secondly, management promoting innovation}

Management promoting innovation has a great impact on the efficiency of innovation. An effective management method that creates motivation for employees to promote their ability to work, foster and develop creative ideas is a premise to create a big step in the innovation process. In particular: (i) it is necessary to focus on decentralization and empowerment so that everyone has the opportunity to perform the assigned work in the most creative and effective way; (ii) there is a need to improve the innovation capacity of employees through organizing training courses, training programs, seminars; (iii) it is crucial to create an appropriate process and set criteria in order to select the innovation ideas; because the selection and nurturing of innovative ideas will contribute to enriching the innovative solutions of enterprises; (iv) there is a need to develop a clear, appropriate and effective implementation plan for developing new ideas and new solutions; (v) focusing on providing feedback on creative ideas of employees is required to help them perfect their ideas or reject the implementation of ideas that are not feasible and applicable.

\section{Thirdly, leadership inspiring innovation}

The leadership significantly affects the innovation capacity of enterprises. Encouraging and inspiring employees to actively innovate would create many breakthroughs that contribute to improving the innovation in enterprises. An inspirational leader plays an important role in creating an open working environment, an open corridor that promotes a culture of innovation in business development. It is one of the important prerequisites that contribute to the improvement and high efficiency of innovation of businesses. Specifically, (i) business leaders should show their enthusiasm for innovation and perfect working conditions of subordinates; (ii) business leaders should constantly listen to and encourage new ideas from employees. Listening and having plans to encourage new ideas will create the motivation for employees to express innovative and creative ideas. In addition, regularly listening to employees also helps leaders to capture information and current status, so that they can make timely plans to promote good creative ideas and abandon fruitless alternatives; (iii) business leaders need to implement many measures to attract people to work on plans for future development. When the employees are clear about the future plans of the company, they would have a better 
orientation and plans for their current jobs as they relates to the long-term development of enterprises.

\section{Fourthly, disseminating/ sharing knowledge in enterprises}

Increasing the dissemination and sharing of knowledge within the enterprises will contribute to improving the capacity of employees in terms of knowledge, skills, and will increase the cohesion among employees. Therefore, in order to promote innovation, the businesses need to enhance the dissemination and knowledge-sharing internally. Particularly, (i) there is a need to build databases, meeting rooms to display and disseminate knowledge, so that all employees can regularly access knowledge. This, in turn, can help employees broaden their knowledge in term of applying technological advances, improving working methods, promoting business innovation; (ii) enterprises also need to hold seminars and workshops to share and disseminate new knowledge to all members; (iii) enterprises also need to have forms of documents and regulations that are easily accessible for workers when they need them. At the same time, the businesses should periodically send appropriate reports and information to employees which could help them timely grasp the necessary information, adjust the processes and reasonable working methods to increase their working efficiency.

\section{Conclusion}

The results of this study show that there are eight factors affecting the innovation activities of enterprises in Binh Dinh, Vietnam, including: (i) Management promoting innovation; (ii) Market research capacity; (iii) Leaders inspiring innovation; (iv) Culture of innovation; (v) Capable human resources for innovation; (vi) Network connection; (vii) Disseminating and sharing knowledgeand (viii) Impact of producing/serving technology. Among the above eight factors, there are four factors that have a strong influence on the innovation activities of enterprises, including: (i) Market research capacity; (ii) Management promoting innovation; (iii) Leaders inspiring innovation and (iv) Disseminating/ sharing knowledge. This shows that most factors that strongly influence innovation are internal to the enterprise. Therefore, businesses need to strengthen their internal resources to improve the efficiency of innovation.

The authors are aware that this investigation of the factors influencing the innovation of the enterprises through a survey of 200 samples companies in Binh Dinh is not strong enough to reach final conclusions. Therefore, it is neccesary to extend the sample size to cover businesses in all provinces and cities across the country in future research. Despite this limitation, we still believe that this research is a significant contribution to the empirical literature on the innovation of Vietnamese enterprises.

\section{References}

Acs, Z. J., \& Audretsch, D. B. (1988). Innovation and firm size in manufacturing. Technovation, 7(3), 197-210.

Afuah, A. (2003). Innovation management: Oxford, UK: Oxford University Press.

Amara, N., Landry, R., \& Doloreux, D. (2009). Patterns of innovation in knowledge-intensive business services. The Service Industries Journal, 29(4), 407-430.

Artz, K. W., Norman, P. M., \& Hatfield, D. E. (2003). firm performance: a longitudinal study of $R \& D$, patents, and product innovation. Academy of Management Proceedings, 1-8. https://doi.org/10.5465/ambpp.2003.13792264.

Assink, M. (2006). Inhibitors of disruptive innovation capability: a conceptualmodel.European JournalofInnovation Management, 9(2), 215-233. https://doi.org/10.1108/14601060610663587.

Avlonitis, G. J., Kouremenos, A., \& Tzokas, N. (1994). Assessing the innovativeness of organizations and its antecedents: Project Innovstrat. European Journal of Marketing, 28(11), 5-28. https://doi.org/10.1108/03090569410075812.

Basuki, B., Pulungan, N. A. F., \& Udin, U. (2020). The Effect of Innovation on Price to Book Value: The Role of Managerial Ownership in Indonesian Companies. Journal of Asian Finance, Economics and Business, 7(5), 249-258. https://doi. org/10.13106/jafeb.2020.vol7.no5.249

Becheikh, N., Landry, R., \& Amara, N. (2006). Lessons from innovation empirical studies in the manufacturing sector: A systematic review of the literature from 1993-2003. Technovation, 26(5-6), 644-664.

Bhattacharya, M., \& Bloch, H. (2004). Determinants of innovation. Small Business Economics, 22(2), 155-162.

Bigliardi, B., \& Dormio, A. I. (2009). An empirical investigation of innovation determinants in food machinery enterprises. European Journal of Innovation Management, 12(2), 223-242. https://doi.org/10.1108/14601060910953988

Cavusgil, S. T., Calantone, R. J., \& Zhao, Y. (2003). Tacit knowledge transfer and firm innovation capability. The Journal of Business and Industrial Marketing, 18(1), 6-21.

Chandy, R. K., \& Tellis, G. J. (1998). Organizing for radical product innovation: The overlooked role of willingness to cannibalize. Journal of Marketing Research, 35(4), 474-487.

Chiu, S.-H., \& Lin, T.-Y. (2019). Evaluation of Regional Knowledge Innovation System in China: An Economic Framework Based on Dynamic Slacks-based Approach. Journal of Asian Finance, Economics and Business, 6(3), 141-149. https://doi. org/10.13106/jafeb.2019.vol6.no3.141.

Chuang, L.-M., Liu, C.-C., Tsai, W.-C., \& Huang, C.-M. (2010). Towards an analytical framework of organizational innovation in the service industry. African Journal of Business 
Management, 4(5), 790-799. https://academicjournals.org/ journal/AJBM/article-full-text-pdf/D6B790C23352

Darroch, J. (2005). Knowledge management, innovation and firm performance. Journal of Knowledge Management, 9(3), 101115. https://doi.org/10.1108/13673270510602809

Dibrell, C., Davis, P. S., \& Craig, J. (2008). Fueling innovation through information technology in SMEs. Journal of Small Business Management, 46(2), 203-218.

Dinh, H. P., Vo, N. V., \& Tran, P. (2018). Quantitative research in Accounting - Auditing. Hanoi: Financial Publishing House.

Erdil, S., Erdil, O., \& Keskin, H. (2004). The relationships between market orientation, firm innovativeness and innovation performance. Journal of Global Business and Technology, 1(1), $1-11$.

Fagerberg, J., \& Godinho, M. M. (2004). Innovation and catchingup. Chapter 20 of the Handbook of Innovation, 1-16.

Fell, D. R., Hansen, E. N., \& Becker, B. W. (2003). Measuring innovativeness for the adoption of industrial products. Industrial Marketing Management, 32(4), 347-353.

Hage, J. T. (1999). Organizational innovation and organizational change. Annual Review of Sociology, 25(1), 597-622.

Herrmann, A., Tomczak, T., \& Befurt, R. (2006). Determinants of radical product innovations. European Journal of Innovation Management, 9(1), 20-43. https://doi. org/10.1108/14601060610640005

Hoang, T., \& Chu, N. M. N. (2011). Applied Statistics in SocialEconomic Analysis. Hanoi, Vietnam: Labour and Social Publishing House.

Hoang, C. C., \& Ngoc, B. H. (2019). The Relationship between Innovation Capability and Firm's Performance in Electronic Companies, Vietnam. Journal of Asian Finance, Economics and Business, 6(3), 295-304. https://doi.org/10.13106/jafeb.2019. vol6.no3.295

Hu, M.-L. M., Horng, J.-S., \& Sun, Y.-H. C. (2009). Hospitality teams: Knowledge sharing and service innovation performance. Tourism Management, 30(1), 41-50.

Jensen, P. H., \& Webster, E. (2009). Another look at the relationship between innovation proxies. Australian Economic Papers, $48(3), 252-269$.

Kheng, Y. K., June, S., \& Mahmood, R. (2013). The determinants of innovative work behavior in the knowledge intensive business services sector in Malsaysia. Asian Social Science, 9(15), 4759.

Le, T. M. L \& Nguyen, N. H. (2017). International experience to improve innovation capacity for businesses and lessons for Vietnam. The Journal of Economics \& Development, 237(3), 95-102.

Lee, J. W., \& Xuan, Y. (2019). Effects of Technology and Innovation Management and Total Factor Productivity on the Economic Growth of China. Journal of Asian Finance, Economics and
Business, 6(2), 63-73. https://doi.org/10.13106/jafeb.2019. vol6.no2.63

Love, J. H., \& Roper, S. (1999). The determinants of innovation: $\mathrm{R} \& \mathrm{D}$, technology transfer and networking effects. Review of Industrial Organization, 15(1), 43-64.

McMillan, C. (2010). Five competitive forces of effective leadership and innovation. Journal of Business Strategy, 31(1), 11-22. https://doi.org/10.1108/02756661011012741

Neely, A., \& Hii, J. (1998). Innovation and business performance: a literature review. The Judge Institute of Management Studies, University of Cambridge, 1-49. http://ecsocman.hse.ru/ data/696/521/1221/litreview_innov1.pdf

Nguyen, Q. D. (2015). Innovation and impact factors - a summary of theoretical basis. The Journal of Economics \& Development, 211(2), 37-46.

O'Connor, G. C., \& Ayers, A. D. (2005). Building a radical innovation competency. Research-Technology Management, 48(1), 23-31.

OECD, E. (2005). Oslo manual: Guidelines for collecting and interpreting innovation data. Paris 2005, Sp, 46. http://dx.doi. org/10.1787/9789264013100-en.

Phung, X. N., \& Le, Q. (2013). Innovation of companies of Vietnam. The Journal of science of Vietnam National University, Economics and Business, 29(4), 1-11.

Prajogo, D. I., \& Sohal, A. S. (2003). The relationship between TQM practices, quality performance, and innovation performance. International Journal of Quality \& Reliability Management, 20(8), 901-918. https://doi.org/10.1108/02656710310493625

Romijn, H., \& Albaladejo, M. (2002). Determinants of innovation capability in small electronics and software firms in southeast England. Research Policy, 31(7), 1053-1067.

Schulze, A., \& Hoegl, M. (2008). Organizational knowledge creation and the generation of new product ideas: A behavioral approach. Research Policy, 37(10), 1742-1750.

Schumpeter, J. (1942). Creative destruction-Capitalism, socialism and democracy (Vol. 825). New York City, NY: Harper and Brothers.

Singh, S., Singh, S., \& Gautam, S. (2009). teaching styles and approaches: medical studentâ€ $€^{\mathrm{TM}} \mathrm{S}$ perceptions of animationbased lectures as a pedagogical innovation. Pakistan Journal of Physiology, 5(1), 16-19. https://pdfs.semanticscholar. org/27d6/168c313283be357c87281ce798f16a3149a6.pdf

Tran, T. H. V. (2016). Factors influencing innovation capability of the shoe enterprises in Hanoi. The Journal of Economics and Management, 74(1), 52-63.

VCCI. (2011). Vietnam Business Annual Report 2011. Hanoi, Vietnam: Information and Communications Publishing House.

Wan, D., Ong, C. H., \& Lee, F. (2005). Determinants of firm innovation in Singapore. Technovation, 25(3), 261-268.

Webster, M. R. (2009). An innovative faculty toolkit: Simulation success. Nurse Educator, 34(4), 148-149. 